\title{
Analisis Komunikasi Keluarga dalam Mentransformasikan Nilai-Nilai Budaya To Lotang di Kabupaten Sidrap
}

\author{
Tuti Bahfiarti, Isfaiqatul Chotimah, Dhia Naufalina Ilmi, Anggriani \\ Departemen Ilmu Komunikasi, Fakultas Ilmu Sosial dan Ilmu Politik, Universitas Hasanuddin, Makassar \\ E-mail: tutibahfiarti@unhas.ac.id
}

DOI: https://doi.org/10.21107/ilkom.v15i2.12419

\begin{abstract}
ABSTRAK
Komunitas To Lotang memiliki spesifikasi keunikan dalam mentransformasi sistem budaya, nilai, kepercayaan dan keyakinan dari generasi ke generasi. Komunitas To Lotang konsisten mempertahankan identitas, kepercayaannya, dan nilai-nilai budayanya. Faktor orang tua berperan penting dalam mentransfer nilai-nilai budaya To Lotang dari terpaan modernisasi. Tujuan penelitian adalah menganalisis komunikasi keluarga dalam mentransformasi nilai-nilai budaya To Lotang di Kabupaten Sidrap. Metode penelitian adalah kualitatif, mengacu pada studi kasus yang secara spesifik mendeskripsikan perilaku subjek keluarga To Lotang dalam mendidik dan mentransformasi nilai-nilai budaya. Lokasi penelitian di Kecamatan Amparita, Kabupaten Sidrap, Provinsi Sulawesi Selatan sebagai tempat berdomisili komunitas To Lotang. Informan penelitian dipilih melalui purposive sampling dengan menentukan tujuh keluarga To Lotang yang konsisten mendidik anak-anak memahami budaya di lingkungannya. Hasil penelitian menunjukkan bahwa proses transformasi nilai-nilai budaya melalui tahapan melihat, membiasakan, dan menstimuli anak-anak dalam prosesi-prosesi ritual adat. Ketiga, tahap memberikan pemahaman dengan cara berkomunikasi melalui tudang sipulung (duduk bersama). Ketiga, tahapan keterlibatan aktif anak-anak dalam prosesi ritual mulai persiapan sampai pelaksanaannya. Keempat, tahap mengingatkan implementasi ajaran dari Uwa'ta atau orang yang dituakan. Kontribusinya pada pelestarian nilai-nilai budaya To Lotang sangat identic melalui organisasi terkecil, seperti lingkungan keluarga.
\end{abstract}

Kata Kunci: Komunikasi Keluarga, To Lotang, Nilai Budaya, Kabupaten Sidrap

\section{ABSTRACT}

The To Lotang community has unique specifications in transforming cultural systems, values, beliefs and beliefs from generation to generation. The To Lotang community consistently maintains its identity, beliefs, and cultural values. The parent factor plays an important role in transferring To Lotang cultural values from the exposure of modernization. The purpose of the study was to analyze family communication in transforming To Lotang cultural values in Sidrap Regency. The research method is qualitative, referring to case studies that specifically describe the behavior of the To Lotang family subjects in educating and transforming cultural values. The research location is in Amparita District, Sidrap Regency, South Sulawesi Province as the place of domicile for the To Lotang community. Research informants were selected through purposive sampling by determining seven To Lotang families who consistently educate children to understand the culture in their environment. The results showed that the process of transforming cultural values through the stages of seeing, familiarizing, and stimulating children in traditional ritual processions.

Cite this as :

Bahfiarti, Tuti., Isfaiqatul C., Dhia N.I., Anggriani (2021). Analisis Komunikasi Keluarga dlam Mentransformasi Nilai-nilai Budaya To Lontang di Kabuoaten Sidrap. Jurnal Komunikasi, 15(2), 169-180. doi: https://doi.org/10.21107/ilkom.v15i2.12419
Article History :

Received August, $18^{\text {th }}$ 2021, Acepted September, 17th 2021

C 2021 Author (s) 
Third, the stage of providing understanding by communicating through tudang sipulung (sitting together). Third, the stages of active involvement of children in the ritual procession from preparation to implementation. Fourth, the stage of reminding the implementation of the teachings of Uwa'ta or elders. His contribution to the preservation of To Lotang's cultural values is very identical through the smallest organization, such as the family environment.

Keywords: Family Communication, Towani To Lotang, Cutural Value, Sidrap Regency

\section{PENDAHULUAN}

Komunitas lokal To Lontang memiliki nilai dan kepercayaan yang spesifik dan unik dalam masyarakat Sulawesi Selatan, khususnya di Kecamatan Amparita Kabupaten Sidrap. Komunitas ini sangat spesifik dan memiliki keunikan dari aspek kepercayaan yang dianut dan diyakini. Perkembangan modernitas akibat kuatnya pengaruh modernisme yang membedakan posisi masyarakat modern dan masyarakat lokal tetap mereka pertahankan. Sebagai penggambaran bahwa masyarakat modern di perkotaan cenderung diidentikkan dengan masyarakat yang cemerlang, beradab, dan hebat. Di sisi lain masyarakat lokal yang hidup di lereng gunung atau di daerah terpencil cenderung dikategorikan kelompok masyarakat terbelakang, dan lemah. Namun, di sisi lain masyakarat ini sangat konsisten mempertahankan nilai-nilai budaya lokal, bahkan cenderung membentengi diri dari perkembangan modernitas yang semakin modern.

\begin{tabular}{lrcr}
\multicolumn{2}{c}{ Komunitas To Lotang } & merupakan \\
penganut kepercayaan & di & Kelurahan \\
Amparita, & Kecamatan & Tellu & Limpoe
\end{tabular}
Kabupaten Sidrap. Berdasarkan sejarah bahwa To Lotang bukanlah penduduk asli Amparita, namun berasal dari kelurahan Wani di Kabupaten Wajo. Historis perpindahaan komunitas ini karena Islamisasi di Kerajaan Gowa sekitar pada abad ke-17. Komunitas ini berada di Amparita sebelum Islam masuk di Kerajaan Wajo, sebelum abad ke-16. Secara keseluruhan jumlah penganut kepercayaan sekitar 40 ribu orang termasuk di luar Sulawesi Selatan (Risal, 2002).

Keunikan komunitas To Lotang berpengaruh dalam implementasi kearifan nilai-nilai lokal yang dimaknai tersendiri bagi pemiliknya. Simbolisasi kehidupan mereka diibaratkan bepergian ke suatu wilayah. Dalam proses perjalanan tersebut ada ritual dan rambu-rambu jalan yang harus diikuti untuk selamat sampai ke tujuan. Individu yang tidak memperdulikan rambu-rambu diibaratkan akan mengalami hambatan untuk sampai ke tujuan.

Komunitas To Lotang yang berpegang teguh pada ajaran leluhur maka implikasinya berpengaruh pada individu dan orang lain di sekitarnya (Rusli, 2012). Hal ini terungkap pada prinsip dan filosofi pada saat komunitas ini melakukan ritual. Prinsip dalam memahami ajarannya dalam falsafah Bahasa Bugis adalah narekko napahangngi ajarang tongengtongenna Tolotangnge, majeppu dena gaga masalah. Prinsip dan filosofi di atas bermakna bahwa jika mereka memahami ajaran hakiki dari komunitas To Lotang maka tidak ada masalah.

Dalam implementasi nilai-nilai adat terdapat sebagian kecil dari komunitas To Lotang, tidak memahami ajaran falsafah nenek moyang mereka, sehingga berpotensi menimbulkan hal-hal yang tidak diinginkan. Berdasarkan kasus yang pernah terjadi di komunitas To Lotang adalah kasus perang kelompok antar remaja yang terjadi di Otting. Kurangnya pemahaman kebenaran kepercayaan yang mereka menyebabkan terjadi permusuhan. Sebagai penggambaran bahwa simbolisasi nilai-nilai kearifan lokal yang mereka yakini merupakan faktor umum dalam agama dan aliran kepercayaan.

Selanjutnya, proses transformasi nilainilai dalam komunitas To Lotang sangat penting dalam menanamkan ajaran kepercayaan yang mereka pahami. Untuk itu, 
diperlukan keluarga sebagai organisasi terkecil dalam mengkomunikasikan nilai-nilai yang mereka anut pada anak-anak sejak dini. Faktor peran Uwa'ta juga sangat penting dalam mempertahankan nilai-nilai budaya yang dipegang teguh. Posisi opinion leader dalam masyarakat tradisional sangat kuat pengaruhnya pada komunitasnya. Peran pemimpin adat atau opinion leader, dalam memberikan penyadaran pada ummatnya untuk kembali kepada jalan yang telah digariskan oleh agama atau kepercayaan masing-masing sangat urgen untuk dilakukan (Rusli, 2012).

Konteks komunikasi keluarga menjadi unsur penting dalam proses transformasi nilainilai budaya komunitas To Lotang. Komunikasi keluarga seperti yang dikembangkan McLeon dan Chafee dalam Reardon (1987) memiliki beberapa pola berdasarkan penelitian yang telah mereka lakukan pada masyarakat tradisional di perkampungan maupun masyarakat industri, yakni pola laissez-faire, protektif, pluralistik dan konsensual.

Keluarga menurut Galvin dan Brommel dalam (Tubbs dan Moss, 2005) adalah sekelompok individu yang memiliki keterikatan perkawinan untuk berkomitmen hidup bersama dan menata pengharapan di masa depan. Keluarga inti inilah lingkungan awal anak-anak berinteraksi dan memahami cara orang-orang di sekitarnya. Keluarga merupakan tempat anak belajar dan memahami permasalahan dan kebiasaan yang ada dalam budaya dan identitas mereka dilahirkan dan dibesarkan. Untuk itu hubungan personal antara orang tua dan anak dalam menanamkan nilai-nilai budaya sangat penting. Komunikasi keluarga merupakan ruang untuk saling berbagi dan mengungkapkan perasaan. Hubungan sosial dalam keluarga dapat dibina melalui keluarga sebagai kelas komunikasi pertama (Eadie, 2009).

Pengembangan konteks hubungan keluarga memerlukan komunikasi diantara anggota-anggota yang terlibat. Berdasarkan pandangan Wood (2016) bahwa komunikasi keluarga memiliki ciri dan karakteristik, antara lain: kesetaraan dan keadilan pada seluruh anggota keluarga, akrab dan memiliki proksimity antara semua anggota keluarga, memiliki sikap saling terbuka antara orang tua dan anak, serta sebaliknya, menjaga hubungan baik dengan mengabaikan permasalahan kecil yang dapat mengganggu keakraban hubungan antar keluarga.

Berdasarkan kasus proses transformasi nilai-nilai budaya dalam keluarga komunitas To Lotang perlu untuk mengkaji bentuk dan pola-pola yang mereka kembangkan dalam komunitasnya untuk mempertahankan nilai dan kepercayaan yang telah lama dianut secara turun temurun oleh nenek moyang mereka.

Penelitian-penelitian terhahulu yang relevan mengkaji komunitas To Lotang adalah berfokus pada kepercayaan dan kearifan lokal dalam mempertahankan kepercayaannya, agama dan pola pendidikan yang mereka lakukan dalam masyarakat, khususnya sebagai etnik Bugis (Rusli, 2012), (Nasruddin, 2014) (Farmalinda, 2015), (Ahzanul, 2011). Tinjauan aspek strategi komunikasi dalam menjalin hubungan harmonis dalam masyarakat komunitas To Lotang (Haslindah, 2017). Perilaku politik masyarakat Towani To Lotang (Tang \& Safriadi, 2018).

Penelitian terdahulu lebih dominan mengkaji aspek budaya dan antropologi kepercayaan yang dimiliki komunitas To Lotang. Perbedaan pada penelitian ini terletak pada aspek transformasi nilai-nilai budaya melalui konsep komunikasi keluarga yang diterapkan dalam mendidik anak-anak untuk tetap memahami kepercayaan mereka. Komunikasi keluarga yang efektif cenderungan menerapkan konsep keterbukaan, sikap positif, sikap saling mendukung, kesetaraan dan empati (Devito, 2011).

Selanjutnya, dalam implementasi transformasi nilai-nilai budaya dalam keluarga memanfaatkan teori skema 
hubungan keluarga yang berfokus pada proses interaksi individu dalam keluarga. Teori ini berorientasi pada acara dan strategi skema keluarga berkomunikasi, yakni orientasi percakapan (conversation orientation) dan orientasi kepatuhan (conformity orientation). Setiap keluarga akan mengalami proses komunikasi dalam interaksi individu dengan anggota keluarga (Morrisan, 2009). Dalam Encyclopedia of Communication Theory (Little John, 2009) menjelaskan bahwa ada empat tipe hubungan keluarga yakni pluralistik, protektif, konsensual, dan laissez faire. Tipe ini juga telah dilakukan pengujian oleh McLeon dan Chafee dalam Reardon (1987) pada masyarakat tradisional diperkampungan dan masyarakat industry

Komunikasi keluarga merupakan faktor penting dalam menanamkan nilai-nilai budaya, khususnya masyarakat tradisional. Berdasarkan latar belakang dan fenomena maraknya modernisasi dengan perkembangan teknologi informasi, media baru termasuk media sosial yang juga memasuki ranah komunitas To Lotang dalam kehidupan mereka sehari-hari.

Keluarga menjadi titik sentral dalam proses menanamkan nilai-nilai budaya tersebut. Terpaan modernisasi menjadikan peran keluarga dan tokoh adat seperti Uwa' dan Uwa'ta sangat penting dalam menjaga kelestarian kepercayaan yang mereka anut dan pertahankan dalam komunitasnya. Penelitian ini bertujuan menganalisis komunikasi keluarga dalam mentransformasi nilai-nilai budaya To Lotang di Kabupaten Sidrap.

\section{METODE PENELITIAN}

Penelitian analisis komunikasi keluarga dalam mentransformasi nilai-nilai budaya To Lotang menggunakan tipe penelitian kualitatif, mengacu pada studi kasus. Pendekatan kualitatif menghasilkan data deskriptif dalam bentuk kata-kata lisan maupun tulisan, perilaku dari individu- individu yang menjadi subjek penelitian (Taylor, Bogdan, 1993). Studi kasus yang digunakan dalam mengeksplorasi, menganalisis kasus pada keluarga To Lotang dalam menerapkan nilai-nilai dan kepercayaan pada anak-anak mereka secara turun temurun. Studi kasus merupakan pendekatan yang menyelidiki fenomena dan konteks dari subjek yang diteliti (Yin, 2013).

Penelitian ini berlokasi di Kelurahan Amparita Kecamatan Tellu Limpoe Kabupaten Sidrap. Pertimbangan representatif memilih lokasi tersebut karena mayoritas penganut ajaran To Lotang berdomisili dan berinteraksi secara langsung dengan masyarakat sesama kepercayaan dan yang berbeda kepercayaan.

Teknik pengumpulan data dilakukan melalui observasi non partisipan dengan cara mengamati aktifitas kehidupan sehari-hari komunitas ini secara langsung. Bentuk observasi non partisipan yang dilakukan terhadap kegiatan keseharian pada komunitas secara keseluruhan. Peneliti juga terlibat langsung dalam keseharian komunitas To Lotang untuk melihat apa saja aktivitas keseharian mereka, mendengar bahasa, cara mendidik dan ritual yang mereka lakukan untuk mentransformasi nilai-nilai budaya untuk mempertahankan kepercayaannya.

Selanjutnya, data dikumpulkan melalui wawancara mendalam (indepth interview) kepada lima keluarga dalam komunitas To Lotang yang memiliki karakteristik spesifik yang ditentukan oleh peneliti. Penentuan Informan dilakukan melalui purposive sampling berdasarkan syarat yang ditetapkan peneliti (Newman, 2006).

Hasil analisis pengamatan atau observasi yang telah dilakukan menjadi dasar menentukan syarat informan yang dijadikan partisipan. Syarat pertama adalah keluarga yang memiliki anak laki-laki atau perempuan berumur 7-17 tahun. Kedua, keluarga yang ayah dan ibu memiliki kepercayaan To Lotang yang sama sehingga proses transformasi nilai- 
nilai budaya dapat dianalisis secara tepat. Ketiga, keluarga yang baik ayah, ibu dan anak-anak yang bersedia dioberservasi dan memberikan jawaban representatif sesuai tujuan penelitian. Setelah melakukan observasi awal ditentukan tujuan keluarga komunitas To Lotang, seperti Tabel 1 berikut:

Tabel 1. Identitas Informan

\begin{tabular}{ccc}
\hline Informan & $\begin{array}{c}\text { Jumlah } \\
\text { Anak }\end{array}$ & Pekerjaan \\
\hline Keluarga A & 5 & Petani \\
\hline Keluarga B & 3 & Pedagang \\
\hline Keluarga C & 5 & Petani \\
\hline Keluarga D & 2 & Petani \\
\hline Keluarga E & 2 & Pedagang \\
\hline Keluarga F & 4 & Petani \\
\hline Keluarga G & 2 & Petani \\
\hline
\end{tabular}

Sumber: Hasil Olahan Data Primer, 2021

Data informan berdasarkan karakteristik yang telah ditentukan dan proses observasi non partisipan dan wawancara mendalam (indepth interview) telah dilakukan. Secara keseluruhan dari tujuh keluarga yang dijadikan informan rata-rata memiliki anak minimal 2 orang yang memiliki rentang usia 7 sampai 17 tahun. Rata-rata keluarga dari pihak ayah bekerja sebagai petani dan pedagang. Keseluruhan istri mereka atau ibu bekerja sebagai ibu rumah tangga. Dalam keluarga peran ibu selain berperan sebagai ibu rumah tangga juga bekerja membantu suami yang berprofesi sebagai petani atau pedagang.

Analisis data penelitian interaktif Miles dan Huberman melalui proses reduksi data yang telah diperoleh melalui wawancara mendalam (indepth interview), data display melalui penyajian kategorisasi hasl reduksi data dalam bentuk tabel. Selanjutnya, tahap simpulan dan verifikasi data (conlusion drawing/verification) (Miles et al., 2014). Analisis data merupakan aktivitas interaktif dan berlangsung secara terus menerus sampai peneliti menemukan data jenuh dan telah memenuhi kriteria representatif berdasarkan tujuan penelitian.

\section{HASIL DAN PEMBAHASAN}

\section{Hasil Penelitian}

Pada dasarnya keunikan komunitas To Lotang adalah kepercayaan yang dianut secara turun temurun dari nenek moyang mereka. Komunitas To Lotang memiliki penampilan sama dengan masyarakat etnik Bugis. Perbedaannya hanya terletak pada kepercayaan mereka yang menyembah dewadewa di atas langit dan laut. Kepercayaan To Lotang telah dianut sebelum etnik Bugis memeluk agama Islam. Kitab suci warga To Lotang Lotang ini adalah kitab.

Penggambaran istilah kata To Lotang adalah 'Tau' dan 'Lotang' yang berarti masyarakat yang berdomisili di wilayah selatan Kota Sidenreng yaitu Amparita. Dalam menjalankan ritual dan kepercayaannya To Lotang dipimpin oleh pemuka masyarakat yang berperan sebagai Uwa. Para pengikut yang tergabung dengan komunitas ini memanggil pemimpinnya sebagai Uwa'ta.

Dalam menjalankan aktifitasnya Uwat'ta didampingi dan dibantu oleh UwaUwa atau bawahan dalam proses pelaksanaan tugasnya. Kelompok Uwa'ta memegang peranan penting dan tokoh yang dijadikan penutan dalam komunitasnya, karena sangat penting serta keluarganya tergolong berdasar dari keluarga bangsawan. Uwa'ta dalam bahasa etnik Bugis bermakna orang yang dituakan atau dipercayai oleh masyarakat di lingkungannya.

Jadi, komunitas To Lotang menjadikan Uwa'ta sebagai orang yang dituakan dan dipercaya menjadi pemimpin dalam berbagai ritual adat dan kepercayaan yang mereka yakini kebenarannya. Uwa'ta sebagai pemimpin yang melaksanakan perekonomian, ritual adat istiadat perkawinan, kelahiran, dan prosesi kematian. Dalam menjalankan keseharian komunitas To Lotang menjalankan hidup saling menghargai, gotong-royong, mufakat dalam mengambil keputusan. Segala aktifitas ini dipandu oleh Uwa'ta sehingga masyarakat sangat menghargai dan 
mendengarkan segala perkataan dan tutur kata dari pemimpin mereka, utamanya dalam menjaga tradisi leluhur mereka.

Berdasarkan hasil penelitian komunikasi keluarga dalam mentransformasi nilai-nilai budaya komunitas To Lotang menunjukkan tingginya keterlibatan orang tua. Peran keluarga (ayah dan ibu) sangat penting dalam mengajarkan, mendidik anakanak mereka untuk taat pada aturan yang dijalankan. Dalam proses pendidikan dan pelestarian nilai-nilai masyarakat To Lotang sangat mengedepankan nilai-nilai keluarga berdasarkan tahapan pendidikan dimulai sejak dari kecil, hingga dewasa. Peran Uwa'ta sangat kuat mentransformasi dan mempertahankan nilai-nilai tahapan pendidikan dalam masyarakat To Lotang.

Selanjutnya, data penelitian lapangan menunjukkan bahwa terdapat empat tahapan transformasi yang dilakukan keluarga terhadap anak-anak. Tahapan ini mulai dari proses stimuli sampai tahap implementasi untuk menanamkan nilai-nilai kepercayaan To Lotang pada generasi mereka. Hasil tahapan yang berfokus pada keluarga berdasarkan hasil kategorisasi data wawancara mendalam (indepth interview) pada tujuh keluarga To komunitas To Lotang yang dijadikan informan. Tahapan transformasi nilai-nilai budaya tersebut, seperti Tabel 1 berikut:

\section{Tabel 2. Tahapan Transformasi Dalam Keluarga To Lotang}

\begin{tabular}{lc}
\hline \multicolumn{1}{c}{$\begin{array}{c}\text { Tahapan Transformasi } \\
\text { Keluarga }\end{array}$} & $\begin{array}{c}\text { Implementasi } \\
\text { Keterlibatan } \\
\text { Keluarga }\end{array}$ \\
\hline $\begin{array}{l}\text { Tahap Melihat, Menstimuli, } \\
\text { dan Membiasakan. }\end{array}$ & Orang Tua \\
\hline $\begin{array}{l}\text { Tahap Pemahaman Melalui } \\
\text { Tudang Sipulung (Duduk } \\
\text { Bersama) }\end{array}$ & $\begin{array}{c}\text { Orang Tua dan } \\
\text { Uwa'ta }\end{array}$ \\
\hline $\begin{array}{l}\text { Tahap Keterlibatan Aktif } \\
\text { Anak Dalam Ritual }\end{array}$ & Orang Tua \\
\hline $\begin{array}{l}\text { Tahap Mengingatkan } \\
\text { Implementasi Ajaran Uwa'ta }\end{array}$ & Orang Tua dan \\
\hline
\end{tabular}

Sumber: Hasil Olahan Data Primer, 2021
Tabel 1, mengindikasikan bahwa pada tahapan pertama adalah tahapan melihat dan membiasakan anak-anak To Lotang secara langsung dilibatkan untuk melihat prosesiprosesi ritual adat. Tujuannya, membiasakan anak-anak dengan ritual-ritual sehingga mereka sejak dini mengenal adat istiadatnya dari generasi ke generasi. Upaya ini sebagai bentuk langsung melestarikan ritual adat masyarakat To Lotang.

Dalam komunitas To Lotang tahap melihat, menstimuli dan membiasakan melalui proses pendidikan dilakukan melalui ritual di dalam perkampungan. Bentuk ritual perkampungan dilakukan komunitas To Lotang. Perkampungan masyarakat To Lotang yang terbesar berada di Amparita dan Kanyuara. Ritual di dalam perkampungan seperti, mappenre nanre (mengantar nasi), pernikahan, kelahiran, syukuran, khitanan, kematian, dan tudang sipulung (duduk bersama). Dalam pelaksanaannya keluarga mengikutsertakan anak-anak setiap pelaksanaan acara ritual sejak dini karena berada di dalam perkampungan sendiri. Kebiasaan orang tua, utamanya ibu mengikutsertakan anak-anak mereka dalam setiap prosesi mulai persiapan sampai pelaksanaan acara ritual.

Hasil penuturan pada keluarga A, adalah:

"setiap ada acara atau kegiatan di dalam
perkampungan saya sebagai ibu selalu
mengikutsertakan anak-anak saya pada
acara mappenre nanre (mengantar nasi),
pernikahan, kelahiran, syukuran
tetangga, khitanan, dan tudang sipulung
(duduk bersama) agar anak-anak tahu
nilai kepercayaan yang kami yakini"
(Wawancara Mendalam, 5 Mei 2021).

Selain ritual di dalam perkampungan terdapat juga acara ritual di luar perkampungan yang pelaksanaannya hanya dilakukan sekali dalam setahun. Ritual ini lokasinya telah ditentukan oleh Uwa'ta berdasarkan kesepakatan dalam Tudang Sipulung (duduk bersama). Ritual ini terdiri dari Perrinyameng di Bulu' Lowa yang 
berada di dekat Amparita, Kecamatan Tellu Limpoe, Kabupaten Sidrap dan di Bulu' Roangnge yang berada di Kelurahan Wattang Bacukiki, Kecamatan Bacukiki, Kota Parepare. Berdasarkan hasil wawancara mendalam yang dilakukan pada keluarga D menuturkan bahwa:

\begin{abstract}
"Kami sekeluarga biasanya melibatkan anak saat ada ritual perkampungan sejak mereka masih kecil. Kegiatan ritual di luar perkampungan di awal kegiatan yang dilaksanakan di Amparita mengalami pendakian cukup lama dengan medan yang cukup sulit". (Wawancara Mendalam, 7 Mei 2021).
\end{abstract}

Prosesi ritual di luar perkampungan dilakukan jauh dari lokasi tempat tinggal komunitas To Lotang. Untuk itu, proses pendidikan dan transformasi nilai-nilai untuk anak-anak dikembalikan kepada orang tua yang ingin melibatkan anak-anak mereka. Kondisi ini disebabkan pendakian yang membutuhkan tenaga dan waktu yang cukup lama sampai dipuncak gunung. Pihak keluarga biasanya mengambil keputusan untuk mengikutsertakan atau tidak membawa anak-anak mereka dalam ritual tersebut. Faktor penentu kegiatan ritual di luar perkampungan sangat ditentukan oleh peran orang tua dalam mengkomunikasikan pada seluruh keluarga. Kesanggupan orang tua sangat diperlukan karena harus melewati jalan yang sulit dan waktu yang lama, seperti di Bulu Roangnge membutuhkan waktu selama 5 jam pendakian untuk mencapai lokasi pelaksanaan ritual.

Tranformasi nilai-nilai To Lotang dilakukan melalui tahapan kedua, yakni tahap memberikan pemahaman dengan cara diajak berkomunikasi melalui diskusi melalui tudang sipulung (duduk bersama). Acara ini sebagai salah wadah berkumpul oleh Uwa'ta atau orang-orang yang dituakan untuk membicarakan prosesi ritual yang akan mereka dilakukan. Dalam kegiatan tudang sipulung (duduk bersama) komunitas To Lotang membicarakan segala bentuk nilainilai dan kepercayaan yang mereka anut dalam kehidupan sehari-hari. Tujuannya, melekatkan nilai-nilai budaya yang mereka laksanakan secara turun temurun.

Tahapan ketiga adalah keterlibatan masyarakat seluruh keluarga To Lotang dilibatkan secara aktif dalam persiapan ritual dan pelaksanaannya. Keterlibatan secara aktif dari anak-anak dilakukan secara sukarela dan tidak ada paksaan terhadap individu untuk mengikuti kegiatan ini. Faktor keluarga sangat berperan untuk secara langsung melibatkan anak-anak mereka dalam mempersiapkan segala ritual. Komunitas ini biasa mempersiapkan segala ritual, seperti Ritual di dalam perkampungan seperti mappenre nanre (mengantar nasi), pernikahan, kelahiran, syukuran, khitanan, kematian, dan tudang sipulung (duduk bersama).

Selanjutnya tahapan keempat adalah tahap mengingatkan yang diterapkan pada seluruh ajaran yang telah disampaikan dari Uwa'ta atau orang yang dituakan dalam komunitas ini. Tahap ini merupakan implementasi secara langsung termasuk setiap keluarga To Lotang yang diterapkan dalam kehidupan sehari-hari. Tahapan ini terjadi secara spontan dan tidak ada waktu khusus penerapannya. Tetua Uwa'ta atau kerabatkerabat yang dituakan secara langsung melakukan pengingatan pada ajaran-ajaran To Lotang yang harus mereka teladani. Tahap mengingatkan implementasi ajaran dari Uwa'ta atau orang yang dituakan. Kontribusinya pada pelestarian nilai-nilai budaya To Lotang melalui organisasi terkecil, seperti keluarga. Bentuk implementasi proses transformasi nilai-nilai sangat ditentukan oleh peran aktif keluarga dalam mengimplementasikan ajaran yang telah disampaikan dan diajarkan oleh Uwa'ta.

Berdasarkan data ditemukan tingkat partisipasi aktif keluarga tergolong tinggi ditandai dengan mengikuti empat tahapan dalam mempertahankan nilai-nilai To Lotang, seperti membiasakan anak-anak terlibat untuk melihat prosesi-prosesi ritual adat. Contohnya mengikutsertakan anak-anak pada ritual di dalam dan di luar perkampungan mereka. Memberikan pemahaman dan mengajak 
berkomunikasi secara terbuka melalui melalui diskusi di tudang sipulung (duduk bersama). Pelibatan aktif aktif anak-anak dalam persiapan ritual dan pelaksanaannya menjadi cara dan strategi keluarga menanamkan nilainilai budaya To Lotang sejak dini. Implementasi ajaran kepercayaan yang dianut turut melibatkan Uwa'ta atau orang yang dituakan. Tujuannya menjaga pelestarian nilai-nilai budaya To Lotang melalui organisasi terkecil, seperti keluarga. Berikut penggambaran tingkat keterlibatan keluarga dalam mentransformasi nilai-nilai budaya $T o$ Lotang, seperti Tabel 3 berikut:

Tabel 3. Tingkat Keterlibatan Keluarga dalam Mentransformasi Nilai-Nilai To Lotang

\begin{tabular}{lcc}
\hline Informan & $\begin{array}{c}\text { Tingkat } \\
\text { Keterlibatan }\end{array}$ & Kategori \\
\hline Keluarga A & Tinggi & Mengikuti \\
& & $\begin{array}{c}\text { Empat Tahapan } \\
\text { Transformasi }\end{array}$ \\
\hline Keluarga B & Tinggi & Mengikuti \\
& & $\begin{array}{c}\text { Empat Tahapan } \\
\text { Transformasi }\end{array}$ \\
\hline Keluarga C & Tinggi & Mengikuti \\
& & Empat Tahapan \\
& & Transformasi \\
\hline Keluarga D & Sedang & Mengikuti Dua \\
& & Tahapan \\
& & Transformasi \\
\hline Keluarga E & Tinggi & Mengikuti \\
& & Empat Tahapan \\
& & Transformasi \\
\hline Keluarga F & Tinggi & Mengikuti \\
& & Empat Tahapan \\
& & Transformasi \\
\hline Keluarga G & Sedang & Mengikuti Dua \\
& & Tahapan \\
& & Transformasi \\
\hline & &
\end{tabular}

Sumber: Hasil Olahan Data Primer, 2021

\footnotetext{
Tingkat keterlibatan keluarga berdasarkan data ditemukan tingkat partisipasi aktif keluarga tergolong tinggi ditandai dengan mengikuti empat tahapan
}

dalam mempertahankan nilai-nilai To Lotang, seperti membiasakan, mengikutsertakan sampai tahap implementasi dalam keluarga. Tingkat keterlibatan sedang ditandai dengan keluarga yang hanya mengikuti dua tahapan tarnformasi nilai-nilai budaya To Lotang. Hasil temuan di lapangan menemukan kategori tinggi ada pada keluarga $\mathrm{A}$, keluarga $\mathrm{B}$, keluarga $\mathrm{C}$, keluarga $\mathrm{E}$, dan keluarga $\mathrm{F}$. Kategori sedang adalah keluarga $\mathrm{D}$ dan keluarga $\mathrm{G}$ yang hanya mengikuti dua tahapan transformasi dari empat tahapan dalam mempertahankan nilai-nilai To Lotang, seperti membiasakan anak-anak terlibat untuk melihat prosesi-prosesi ritual adat dsampai tahap implementasi nilai-nilai tersebut.

Hasil penelitian komunikasi keluarga dalam mentransformasi nilai-nilai budaya $T o$ Lotang lebih menonjolkan strategi skema hubungan keluarga dalam berkomunikasi. Teknik dan strategi berkomunikasi antar keluarga berdasarkan ada dua yakni orientasi percakapan dan orientasi kepatuhan (Morrisan, 2013). Orientasi percakapan, yakni komunitas ini memaksimalkan peran keluarga dalam proses interaksi dengan menstimuli anak, berdiskusi dan mengikusertakan anak dalam penanaman nilai-nilai ritualnya. Selanjutnya, orientasi kepatuhan dari keluarga untuk konsisten mendidik anak-anak mereka melaksanakan budayanya. Hal ini diperkuat dengan keterlibatan Uwa'ta sebagai tokoh sentral dalam melestarikan nilai-nilai budaya To Lotang.

Lebih lanjut konsep Morrisan (2013) yang menjelaskan empat tipe keluarga, yakni tipe pluralistik, tipe protektif, konsensual, dan tipe laissez faire. Berdasarkan hasil temuan penelitian menunjukkan bahwa komunikasi keluarga yang efektif dalam sebuah keluarga untuk dapat membantu anak berkembang adalah sikap saling mendukung dalam keluarga. Berdasarkan hasil wawancara mendalam (indepth interview) dan observasi terdapat tiga karakteristik yang diaplikasikan dalam keluarga To Lotang.

Tipe keluarga pluralistik merupakan keluarga yang berfokus pada orientasi 
percakapan meskipun hasilnya terjadi kepatuhan rendah. Tipe pluralistik terjadi pada keluarga $D$ dan keluarga $G$ yang memanfaatkan percakapan dalam menanamkan nilai-nilai budaya To Lotang. Faktor percakapan dan diskusi dalam hubungan keluarga dominan dalam tipe ini, namun tingkat kepatuhan cenderung masih minim. Artinya bahwa, ada kecenderungan anak untuk tidak ingin terlibat langsung dalam prosesi ritual yang dilakukan di komunitasnya.

Tipe keluarga konsensual yang menunjukkan dominasi kewenangan orang tua (ayah atau ibu) dalam memberikan pengaruh positif terhadap tranformasi nilainilai budaya To Lotang serta pendidikan anak dalam keluarga. Jika dipadukan dengan orientasi percakapan dan komunikasi saling terbuka maka akan menghasilkan kepatuhan yang tinggi. Dalam penelitian ini tipe konsensual terjadi pada keluarga A, keluarga $\mathrm{B}$, dan keluarga $\mathrm{C}$ yang mengkomunikasikan secara jelas setiap ritual yang diikuti bersama keluarga pada saat anak-anak mereka sudah bisa diajak berkomunikasi. Dalam tipe konsensual anak-anak cenderung patuh untuk mengikuti intsruksi dan ajakan orang tua untuk mengikuti prosesi ritual dan ajarannya.

Tipe protektif berorientasi pada dominasi orang tua terhadap anak. Dominasi pada proses pengambilan keputusan biasanya dilakukan secara otoriter atau satu pihak. Orang tua cenderung mendominasi anak dan kurang melakukan komunikasi secara terbuka dalam proses hubungan keluarga. Dalam penelitian ini orang tua cenderung memberikan perintah pada anak untuk mengikuti atau mentransformasi nilai-nilai budaya To Lotang yang mereka percayai dan yakini. Tipe protektif terjadi pada keluarga $\mathrm{E}$ dan keluarga F. Pada keluarga yang menganut tipe protektif ini memiliki keunikan karena berada pada kategori tinggi tingkat tranformasi nilai-nilai kepercayaan yang ditanamkan pada anak-anak mereka. Kondisi ini disebabkan oleh tahapan implementasi secara langsung pada anak-anak mulai dari kecil sampai dewasa secara rutin dan berkelanjutan.

Keunikan hasil penelitian ini adalah tipe keluarga yakni, tipe pluralistik, tipe protektif, dan tipe konsensual yang diterapkan dalam keluarga (Morrisan, 2013) menghasilkan hasil transformasi kategori tinggi dan sedang. Faktor ini disebabkan kaluarga To Lotang sangat mendukung dan melibatkan anak secara langsung dalam prosesi ritual. Prosesi tersebut dilaksanakan di dalam perkampungan, seperti mappenre nanre (mengantar nasi), pernikahan, kelahiran, syukuran, khitanan, kematian, dan tudang sipulung (duduk bersama). Keluarga dalam hal ini ayah dan ibu mengikutsertakan anak-anak mereka pada ritual di dalam perkampungan, Selanjutnya, ritual luar perkampungan didasarkan pada kesanggupan orang tua mengikutsertakan anak mereka. Ritual seperti Perrinyameng di laksanakan jauh dari rumah masyarakat karena pelaksanaannya di Bulu' Lowa yang berada di dekat Amparita, dan di Bulu' Roangnge di Kelurahan Wattang Bacukiki.

Dalam konteks komunikasi keluarga juga diaplikasikan efektifitas komunikasi interpersonal yang dikembangkan (Devito, 2011). Konsep tersebut adalah keterbukaan (openness) antara orang tua dan anak dalam mempelajari nilai-nilai budaya mereka. Sikap empati (emphathy) melalui saling memahami posisi dalam mempelajari nilai-nilai tersebut. Sikap mendukung (supportiveness) orang tua sangat mendukung anak untuk belajar dan terlibat dalam prosesi dan ritual yang mereka lakukan dalam mempertahankan kepercayaan To Lotang.

Sikap positif (positiveness) orang tua mendukung anak-anak mereka untuk mengikuti prosesi ritual baik di dalam perkampuangan maupun di luar perkampuangan. Faktor kesetaraan (equality) juga diterapkan dalam hal kesamaan untuk wajin mengikuti prosesi ritual dan penerapan komunikasi keluarga dari tujuan keluarga yang dijadikan informan penelitian. Konteks penerapan efektifitas komunikasi 
interpersonal dalam keluarga sangat menentukan kualitas hubungan antara orang tua dan anak dalam keluarga.

Lebih lanjut, Miller (2008) dalam Sari dkk (2010) bahwa faktor kedekatan (proksimity) antara orang tua (ayah dan ibu) perlu diterapkan dalam konteks keluarga. Kedekatan sebagai konsep memiliki beberapa komponen yakni, pertama pengetahuan (knowledge) dalam hal ini setiap individu saling berbagi informasi personal termasuk dalam keluarga. Faktor diskusi dan proses penyelesaian bersama dalam keluarga sangat penting. Kedua, adanya rasa kepedulian yakni kasih sayang antara orang tua (ayah dan ibu) serta anak-anak dalam kategori keluarga inti. Ketiga, ketergantungan merupakan orientasi sikap saling ketergantungan dan membutuhkan antara satu sama lainnya dalam keluarga. Keempat, kesetaraan adalah saling menghargai hubungan dan posisi orang tua (ayah dan ibu) serta anak-anak yang tidak saling tumpang tindih posisinya. Kelima, faktor kepercayaan orang tua (ayah dan ibu) kepada anak-anak untuk saling menghargai dan belajar nila-nilai budaya yang mereka yakini dan percayai. Keenam, adanya komitmen berdasa seluruh komponen keluarga untuk saling mendukung dalam menanamkan nilai-nilai budaya dalam kehidupannya.

Faktor saling mengembangkan komunikasi efektif menjadi kunci dalam mentransformasi nilai-nilai budaya To Lotang kepada generasi mereka. Upaya ini juga harus melibatkan komponen tokoh yang dituakan dan dijadikan panutan seperti Uwa'ta dalam mentransformasi nilai-nilai tersebut. Kedekatan antara orang tua dan anak sangat menentukan proses transformasi nilai-nilai budaya termasuk dalam komunitas To Lotang.

Hasil penelitian mengindikasikan keterlibatan orang tua dan anak dalam konteks komunikasi keluarga memiliki dampak positif pada penanaman nilai-nilai budaya. Faktor kesetaraan, kedekatan, keterbukaan, dan keakraban menjadi ciri dan karakteristik komunitas To Lotang yang diterapkan dalam keluarga mereka. Faktor kedekatan dengan Uwa'ta sebagai pemimpin ritual sangat dekat dan secara langsung memberikan arahan dan petunjuk untuk mengajarkan nilai-nilai budaya yang mereka anut.

\section{PENUTUP}

\section{Simpulan}

Hasil penelitian menunjukkan bahwa proses transformasi nilai-nilai budaya To Lotang dilakukan melalui pertama, tahapan melihat dan membiasakan anak-anak To Lotang dilibatkan untuk melihat prosesiprosesi ritual adat. Kebiasaan anak untuk mengikuti ritual di dalam perkampungan dan di luar perkampungan sangat intens dilakukan oleh keluarga (ayah dan ibu). Kedua, tahap memberikan pemahaman dengan cara berkomunikasi melalui tudang sipulung (duduk bersama), Ketiga, tahap keterlibatan aktif anak-anak dalam persiapan ritual dan pelaksanaannya. Keempat, tahap mengingatkan implementasi ajaran dari Uwa'ta atau orang yang dituakan.

Kontribusinya penelitian ini pada pelestarian nilai-nilai budaya To Lotang melalui melalui keluarga sebagai organisasi kecil temapat orang tua dan anak-anak berinteraksi awan dan secara langsung. Faktor keluarga berkontribusi positif pada ketaatan anak dalam mengikuti ajaran kepercayaan $T o$ Lotang.

Sebagai saran pada orang tua dan anak untuk meningkatkan kedekatan dan intensitas komunikasi keluarga melalui keterbukaan, saling mendukung, empati, kesetaraan, dan saling berpikir positif.

Rekomendasi dalam penelitian ini adalah dalam proses transformasi nilai-nilai budaya lebih melibatkan Uwa'ta sebagai orang yang dituakan dalam komunitas ini. Faktor opinion leader dalam masyarakat tradisional memiliki peran dalam mengubah sikap dan perilaku masyarakat. Peran keluarga dalam mentransformasi nilai-nilai budaya $T o$ 
Lotang lebih dimaksimalkan dengan tetap berpegang teguh pada kearifan lokal. Faktor kelompok referensi sebagai kelompok rujukan atau teman sebaya dapat dimaksimalkan untuk memberikan kontribusi dalam proses transformasi nilai-nilai budaya.

Selanjutnya, sebagai kelanjutan penelitian dapat melakukan pengujian secara kuantitatif terhadap penerapan tipe skema hubungan keluarga seperti, tipe pluralistik, tipe protektif, tipe konsensual, dan tipe laissez faire. Tujuannya mengambil data secara objektif dengan jumlah sampel yang lebih besar yakni keluarga komunitas To Lotang.

\section{Ucapan Terima Kasih}

Penelitian analisis komunikasi keluarga dalam mempertahankan nilai-nilai budaya To Lotang didanai oleh Lembaga Penelitian dan Pengabdian Pada Masyarakat (LPPM) Universitas Hasanuddin. Penelitian ini merupakan Penelitian Dosen Penasihat Akademik (PDPA) dengan Surat Keputusan Rektor Nomor 2215/UN4.1/KEP/2021 Tanggal 9 April 2021, Nomor Kontrak 915/UN4.22/PT.01.03/2021. Penelitian kolaboratif antara dosen dan mahasiswa merupakan pembelajaran penelitian dan publikasi yang melibatkan mahasiswa secara langsung. Terima kasih pada tim enumerator lapangan dan mahasiswa yang membantu pelaksanaan dan analisis penelitian ini. Penelitian ini berlangsung atas sumbangsih Departemen Ilmu Komunikasi, Fakultas Ilmu Sosial dan Ilmu Politik Universitas Hasanuddin.

\section{DAFTAR PUSTAKA}

Ahsanul Khalikin, "Eksistensi dan
Perkembangan Kepercayaan
Towani Tolotang di Kecamatan
Tellu Limpoe Kabupaten Sidenreng
Rappang", Jurnal, (Puslitbang
Kehidupan Keagamaan, 2011).

Bogdan, Robert dan Steven J Taylor. 1993. Kualitatif Dasar-Dasar Penelitian (Terjemahan). Surabaya: Usaha Nasional.

Devito, Joseph A. 2011. Komunikasi Antarmanusia. Tangerang Selatan: KARISMA Publishing Group

Eadie, William F. (Eds). (2009). 21stCentury Communication: A Reference Book. California: SAGE Publications, Inc.

Farmalindah, "Komunitas Towani Tolotang Di Amparita Kabupaten Sidenreng Rappang (Studi Kasus Pola Pendidikan Beragama)", Jurnal, 2012.

Haslindah. 2017. Strategi Komunikasi Penganut Kepercayaan To Lotang dalam Menjaga Hubungan Harmonis dengan Masyarakat di Kelurahan Amparita Kecamatan Tellu Limpoe Kabupaten Sidenreng Rappang. Skripsi (Universitas Islam Negeri Alauddin) (Tidak Diterbitkan, 2017).

Littlejohn, Stephen W \& Karen A. Foss.2009. Teori Komunikasi, edisi 9. Jakarta: Salemba Humanika

Mahmud Tang, Safriadi. 2018, Perilaku Politik Towani Tolotang di Amparita Kabupaten Sidenreng Rappang. Dalam jurnal Etnosia: Jurnal Etnografi Indonesia

Morissan, dan Andy Corry Wardhany. 2013. Teori Komunikasi (Tentang Komunikatir, Pesan, Percakapan, dan Hubungan). Bogor: Ghalia Indonesia

Miles, M. ., Huberman, A. ., \& Saldana, J. (2014). Qualitative Data Analysis, 
A Methods Sourcebook, Edition 3. Sage Publications.

Neuman, L. W. (2006). Social Research Methods Qualitative and Quantitative Approaches. Pearson Education, Inc.

Nasruddin, "Budaya Bugis dan Agama Hindu Tolotang di Kelurahan Amparita Kecamatan Tellu Limpoe Kabupaten Sidrap (Kajian Antropologi Budaya)", Jurna 1 (AlKalam Vol. VIII, 2014).

Rusli, Muhammad. 2012. Kearifan Lokal Masyarakat Towani Tolotang Di Kabupaten Sidenren Rappang. Dalam Jurnal Al- Ulum Volume. 12 ,

Reardon KK 1987. Interpersonal Communication Where Winds Meet. Wadsworth Publishing Company, California.

Risal, Ahmad "Sejarah Tolotang", Makkawaruwe.blogspot.com. http://makkawaruwe.blogspot.com/ 20/15/02/sejarahtolotang.html,\%20diakses\%20tang gal\%2028\%20Juni\%202017.

Sari, Hubeis, Mangkuprawira, dan A. Saleh. Komunikasi Keluarga dalam Fungsi Sosialisasi Keluarga terhadap Perkembangan Anak. Jurnal Komunikasi Pembangunan ISSN 1693-3699 Juli 2010, Vol. 08, No. 2.

Tubbs, Stewart L., dan Sylvia Moss. (2005). Human Communication: PrinsipPrinsip Dasar. Diterjmahkan oleh: Deddy Mulyana dan Gembirasari. Bandung: PT Remaja Rosdakarya.

Wood, Julia T. (2016). Interpersonal Communication: Everyday Encounter. 8 th edition. Canada: Cengage Learning.

Yin, R. K. 2008. Case Study Research: Design and Methods. Sage Publications. 